\title{
Emergency Room Consultations: Problems and Solutions
}

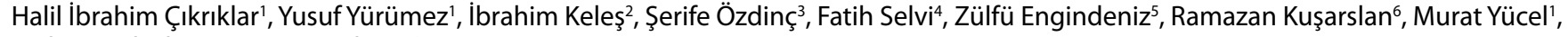 \\ Mehmet Ali Ekici ${ }^{7}$, Canan Baydemir ${ }^{8}$ \\ 'Department of Emergency Medicine, Sakarya University Faculty of Medicine, Sakarya, Turkey \\ ${ }^{2}$ Department of Urology, Afyon Kocatepe University Faculty of Medicine, Afyonkarahisar, Turkey \\ ${ }^{3}$ Department of Emergency Medicine, Afyon Kocatepe University Faculty of Medicine, Afyonkarahisar, Turkey \\ ${ }^{4}$ Department of Emergency Medicine, Ağrı State Hospital, Ağrı, Turkey \\ ${ }^{5}$ Department of Emergency Medicine, Muradiye State Hospital, Bursa, Turkey \\ ${ }^{6} \mathrm{Clinic}$ of General Surgery, Ministry of Health İstanbul Bağcılar Training and Research Hospital, İstanbul, Turkey \\ ${ }^{7}$ Clinic of Neurosurgery, Ministry of Health Şevket Yılmaz Training and Research, Bursa, Turkey \\ ${ }^{8}$ Department of Biostatistics, Eskişehir Osmangazi University Faculty of Medicine, Eskişehir, Turkey
}

\begin{abstract}
Aim: This study aimed at identifying the problems of consultations requested from the emergency department (ED), the solution to these problems, suggestions for physicians to reveal the nature of the issue addressed, and to contribute to the literature because not enough research has been done on this issue yet.

Materials and Methods: This study included emergency and consultant physicians working in six different EDs. Consultation procedures prepared in advance for the most basic problems and questions with solutions to address these issues by filling in the questionnaire were received.

Results: Of the 439 physicians included in the study, 299 were men (68.1\%) and 140 were women (31.9\%). The age of men was between 24 and 62 years, with a mean age of $36.1 \pm 8.1$ years, while the age of women was between 24 and 53 years, with a mean age of $33.3 \pm 6.2$ years. During the process of consultation, emergency physicians experienced the most fundamental problems such as "completing the diagnostic process of the patients in the emergency department and patients requiring hospitalization to be treated in the emergency department" were detected. However, the consultant physicians experienced that "patients were not examined enough by emergency physicians and patient files did not have sufficient information."

Conclusion: A full assessment of the patient before consultation and consultation with the correct branches are requested by consultant physicians. Emergency physicians request to see respect from consultant physicians and not to complete the stages of diagnosis and treatment in the emergency department. (Eurasian J Emerg Med 2015; 14: 167-71)
\end{abstract}

Keywords: Emergency department, consultation, emergency management

\section{Introduction}

The quality of the healthcare service is one of the most important factors that determine the socioeconomic development levels of countries (1). Hospitals are one of the most important parameters that represent the quality of health services. In the quality evaluation of the hospitals, both the operation and the architecture of the emergency services (ES) have a very distinctive role. In other words, ES are accepted as the showcases of the hospitals (2).
When a patient is admitted to an ES, urgent examination of the patient and rapid completion of the procedures of diagnosis and treatment are expected. However, this is not quite possible in reality because, in ES, doctors deal with different cases that may have different problems at the same time and make life-sustaining decisions about the cases in very short time periods. Also, ES are units that have the highest mortality rate (3-5). Moreover, in the beginning, it may not be possible to understand whether or not the patient who came to an ES has an emergency situation. At this stage, every patient must

Correspondence to: Halil İbrahim Çıkrıklar e-mail: halilcikriklar@hotmail.com 
be examined; the necessary laboratory tests should be performed; and in most cases, consultation from the related branches may be needed. It should not be forgotten that consultation is one of the most important stages in this procedure $(1,3,4)$.

Consultation is defined as the situation in which the physician primarily responsible for the patient decides which views and applications of different areas of specialty are needed or, on the patient's request, the physician consults one of his/her colleagues from another branch, takes his/her advice, and continues the follow-up of the patient according to this advice (6-8).

There are two sides in consultation. One side is the doctors working in ES, and the other is the doctors called for consultation. Communication between the two sides and the manner in which they run the consultation procedure $(\mathrm{CP})$ are the factors that determine the effectiveness of this procedure. During the consultation period, if a problem occurs on one of the sides, this appears as a failure in consultation or elongated consultation periods (8-11). As a result of this situation, patients wait for longer periods, which cause patient dissatisfaction $(12,13)$. It is possible to say that an effective consultation process will decrease the waiting period of the patient in an ES, thereby increasing patient satisfaction.

The aim of this study was to determine the problems that are encountered during the consultation process and to determine the suggested solutions for these problems as well as to contribute to the literature because there has not been enough research on this issue.

\section{Materials and Methods}

This study was conducted between 15.04.2012 and 15.06.2012. Out of the 1349 physicians, 439 physicians working in a total of six hospitals, of which two are Medical Faculty Hospitals, two are Training and Research Hospitals, and two are Public Hospitals, joined the study. In the questionnaire, there were questions about demographic information, whether or not there are written $C P$, whether or not the $\mathrm{CP}$ is announced, and the basic problems as well as solutions for them. As a part of the study, emergency and consulting physicians filled in the questionnaire (Questionnaire 1 and 2, respectively). They were requested to give a point value according to the significance level of the problem that they experience from 1 to 10 using a numerical grade scale. Also, the doctors were asked for their solution-oriented personal ideas.

\section{Statistical analysis}

The data was analyzed using the Statistical Package for the Social Sciences version 11.0 (SPSS Inc, Chicago, IL, USA) software. Percentage distribution and mean \pm standard deviation were used.

\section{Results}

Demographic data: Demographic data of the doctors that joined the study are presented in Table 1. In total, 439 doctors joined the study. According to the data, $68.1 \%$ were male, $82.2 \%$ were consulting physicians, and $52.8 \%$ were specialists.

Consultation procedure: There was a CP in three hospitals out of six. In two hospitals, the CP was announced on the website of the institution. In only one hospital, the written announcement of the $\mathrm{CP}$ to all doctors had been performed, and doctors were asked to sign the papers that show they have read the CP. According to the results, the percentage of physicians who had read the $C P$ increased as a result of the written announcement of the CP. Nevertheless, it was found that most of the doctors $(62 \%)$ did not read the document that they signed (Table 2, 3).

Basic problems: The results from the point of view of the consulting physicians are shown in Table 4. According to these results, the three greatest problems are as follows: "patient who needs consultation is not sufficiently examined by an emergency physician," "not having enough information in the patients' file," and "invitation of unnecessary consultation." The results from the point of view of emergency physicians are shown in Table 5. According to the results "trying to complete the diagnostic procedure for the patients in an emergency service" was the main problem. The other two important problems are stated as follows: "Trying to treat patients in an emergency service who need hospitalization" and "not finishing the consultation with a definite statement and writing re-consultation forms."

Solution suggestions: Out of the 361 consulting physicians, 94 gave 135 different suggestions. "Before consultation, sufficient examination and medical workups must be performed" (25.5\%) and "unnecessary consultation should not be requested" (22.3\%) were the suggestions that were prominent (Table 6). The solution suggestions of emergency physicians to improve the consultation process are stated in Table 7.

\section{Discussion}

Emergency service are the most crowded and complicated units in almost all hospitals. The crowdedness in ES originates from the examination without appointment. The major reasons for complexity include the emergency nature of cases in addition to the crowdedness of patients; having a wide clinical diagnosis range; and in most cases, the requirement of a multidisciplinary approach and coordinated work with many other departments $(9,10)$.

Despite the fact that there are too many factors that affect the patient flow in ES, the difficulties encountered during medical consultations are shown to be the major factor (14). Problems encountered during the consultation progress can sometimes be the reason for patients' death and can cause doctors to be found guilty in the eyes of the law. Thus, in recent years, an increase in the number of lawsuits because of doctors' malpractice has been drawing attention.

Table 1. Demographic features

\begin{tabular}{|c|c|c|c|c|c|}
\hline & & $\mathbf{n}$ & $\%$ & Min-Max & Average \\
\hline Age & Male & 299 & 68.1 & $24-62$ & $36.1 \pm 8.1$ \\
\hline & Female & 140 & 31.9 & $24-53$ & $33.3 \pm 6.2$ \\
\hline Subject & Emergency Medicine & 78 & 17.8 & & \\
\hline & Other subjects & 361 & 82.2 & & \\
\hline Degree & Academic & 37 & 8.4 & & \\
\hline & Senior physician & 232 & 52.8 & & \\
\hline & Research assistant & 139 & 31.6 & & \\
\hline & General practitioner & 31 & 7.0 & & \\
\hline
\end{tabular}


Table 2. Answers of physicians related to existence of a $C P$ in hospitals that have a $C P$

\begin{tabular}{|c|c|c|c|}
\hline & & $\mathbf{n}$ & $\%$ \\
\hline \multirow[t]{5}{*}{ Emergency Physicians } & Number of physicians answering "I do not know" & 17 & 39.5 \\
\hline & Number of physicians answering "Yes" & 26 & 60.5 \\
\hline & Number of physicians answering "No" & 0 & 0 \\
\hline & Number of Physician that have read the written "Consultation Procedure" & 6 & 13.9 \\
\hline & Total & 43 & 100 \\
\hline \multirow[t]{5}{*}{ Consulting Physicians } & Number of physicians answering "I do not know" & 97 & $\begin{array}{l}45.7 \\
48.0\end{array}$ \\
\hline & Number of physicians answering "Yes" & 92 & $\begin{array}{l}43.4 \\
45.5\end{array}$ \\
\hline & Number of physicians answering "No" & 13 & $\begin{array}{l}6.1 \\
6.4\end{array}$ \\
\hline & Number of Physician that have read the written "Consultation Procedure" & 41 & $\begin{array}{l}19.3 \\
20.3 \\
\end{array}$ \\
\hline & Total & 212 & 100 \\
\hline
\end{tabular}

Table 3. Answers of physicians who work at the hospital in which the written announcement of a CP is done

\begin{tabular}{|l|c|c|}
\hline & $\mathbf{n}$ & $\%$ \\
\hline Number of physicians answering "I do not know" & 5 & $\begin{array}{c}11.9 \\
15.6\end{array}$ \\
\hline Number of physicians answering "Yes" & 24 & $\begin{array}{l}57.1 \\
75.0\end{array}$ \\
\hline Number of physicians answering "No" & 3 & $7.1-9.4$ \\
\hline Number of Physician that have read the & 16 & $38-50$ \\
written "Consultation Procedure" & & \\
\hline Total & 42 & 100 \\
\hline
\end{tabular}

It is imperative that doctors in both emergency and consulting services should know their duties and responsibilities (3).

In terms of consultation, the body of the current law states that an "emergency physician should request consultation in time from a consulting physician and a consulting physician should also return as soon as possible under any circumstances whatsoever" (15). In addition, it is not identified with distinct borders under which conditions consultation from a specialty physician should be requested; however, to minimize the problems faced, it is suggested to structure a $\mathrm{CP}$ and control system according to the operation of the hospital (3, 16-19). Three out of six examined hospitals in this study have a CP, and only one of them has announced this procedure in written form and required that the doctors sign papers that show they have read the $\mathrm{CP}$, which gives rise to the idea that the hospital administrations does not display necessary sensitivity on this subject.

During the consultation procedure, the consulting physician is expected to, in respect to the consultation request, take care of the patient attentively, make suggestions about diagnosis and treatment, ensure that the suggested treatment is applied, and follow the results of the medical analysis and work collaboratively with the primary physician of the patient. In addition, it is also expected
Table 4. Problems from the point of view of consulting physicians

\begin{tabular}{|l|c|}
\hline & $\begin{array}{c}\text { Score } \\
\text { (Mean } \pm \text { SD) }\end{array}$ \\
\hline $\begin{array}{l}\text { Patient who needs consultation is not sufficiently } \\
\text { examined by an emergency physician }\end{array}$ & $7.00 \pm 2.78$ \\
\hline $\begin{array}{l}\text { Not having enough information } \\
\text { in the patients' file }\end{array}$ & $6.63 \pm 2.86$ \\
\hline Invitation of unnecessary consultation & $6.43 \pm 2.78$ \\
\hline $\begin{array}{l}\text { Insufficiently completed consultation } \\
\text { request forms }\end{array}$ & $6.43 \pm 2.98$ \\
\hline $\begin{array}{l}\text { Physician who wants consultation cannot } \\
\text { be found beside the patient }\end{array}$ & $6.35 \pm 3.13$ \\
\hline $\begin{array}{l}\text { Diagnostic approaches are not performed for } \\
\text { the patient who needs consultation }\end{array}$ & $6.14 \pm 2.94$ \\
\hline $\begin{array}{l}\text { Consultation request is not made in an } \\
\text { appropriate time period }\end{array}$ & $5.45 \pm 3.25$ \\
\hline $\begin{array}{l}\text { Procedure given by consulting physicians are } \\
\text { not fulfilled }\end{array}$ & $5.20 \pm 3.48$ \\
\hline $\begin{array}{l}\text { Patient who needs consultation could not } \\
\text { be found in an emergency service }\end{array}$ & $4.81 \pm 3.35$ \\
\hline SD: standard deviation & \\
\hline
\end{tabular}

that the consulting physician should attempt to help others in his/ her own profession as may be required (15). However, this procedure cannot be conducted salubriously most of the time, and we face a set of problems as a reflection of that situation (11). Also, in our study, the major problems encountered by the emergency physicians during the consultation were stated as follows: "trying to complete the diagnostic procedure for patients in emergency services," "trying to treat patients in emergency services who need hospitalization," "not finishing the consultation with a definite statement and writing re-consultation forms," and "delay by the consulting physician". 
Table 5. Problems from the point of view of emergency physicians

\begin{tabular}{|l|c|}
\hline & $\begin{array}{c}\text { Score } \\
\text { (Mean } \pm \text { SD) }\end{array}$ \\
\hline $\begin{array}{l}\text { Trying to complete the diagnostic procedure } \\
\text { for patients in an emergency service }\end{array}$ & $8.47 \pm 2.30$ \\
\hline $\begin{array}{l}\text { Trying to treat patients who need hospitalization } \\
\text { in an emergency service }\end{array}$ & $8.35 \pm 2.16$ \\
\hline $\begin{array}{l}\text { Not finishing the consultation with a definite } \\
\text { statement and writing re-consultation forms }\end{array}$ & $7.38 \pm 2.68$ \\
\hline Delay by the consulting physician & $7.33 \pm 2.66$ \\
\hline Unnecessary extra consultation request & $7.32 \pm 2.59$ \\
\hline $\begin{array}{l}\text { Consulting physician does not examine the } \\
\text { patient, only gives information via the phone }\end{array}$ & $6.62 \pm 2.66$ \\
\hline Cannot reach the consulting physician & $6.53 \pm 2.95$ \\
\hline Unnecessary medical workup request & $6.13 \pm 2.96$ \\
\hline $\begin{array}{l}\text { Consulting physician does not fill in the } \\
\text { consultation paper }\end{array}$ & $6.09 \pm 3.12$ \\
\hline $\begin{array}{l}\text { Completed consultation paper is not legible and } \\
\text { understandable }\end{array}$ & $6.00 \pm 2.97$ \\
\hline $\begin{array}{l}\text { Nonstandard abbreviations are being used in } \\
\text { consultation papers }\end{array}$ & $4.74 \pm 2.90$ \\
\hline
\end{tabular}

Table 6. Suggestion of consulting physicians to improve the consulting process

\begin{tabular}{|l|c|c|}
\hline & $\mathbf{n}$ & $\%$ \\
\hline $\begin{array}{l}\text { Prior to consultation, sufficient examination and } \\
\text { medical workups must be conducted }\end{array}$ & 24 & 17.8 \\
\hline Unnecessary consultation should not be requested & 21 & 15.5 \\
\hline Other & 90 & 66.7 \\
\hline Total & 135 & 100 \\
\hline
\end{tabular}

Table 7. Suggestion of emergency physicians to improve the consulting process

\begin{tabular}{|l|c|c|}
\hline & $\mathbf{n}$ & $\%$ \\
\hline $\begin{array}{l}\text { There should not be unnecessary extra consultation } \\
\text { requests }\end{array}$ & 4 & 8.3 \\
\hline $\begin{array}{l}\text { Consulting physicians must be kept informed about } \\
\text { having a more appropriate and respectful attitude }\end{array}$ & 4 & 8.3 \\
\hline $\begin{array}{l}\text { Consulting physician must be in contact with } \\
\text { other subject physicians and make an effort to } \\
\text { conclude on the patient's situation }\end{array}$ & 4 & 8.3 \\
\hline Consulting physician must take care of the patient & 4 & 8.3 \\
\hline $\begin{array}{l}\text { Consulting physician must be easily accessible and } \\
\text { communication obstacles must be overcome }\end{array}$ & 4 & 8.3 \\
\hline $\begin{array}{l}\text { Consulting physician must respond to the } \\
\text { consultation invitation on time }\end{array}$ & 3 & 6.2 \\
\hline Other & 25 & 52.1 \\
\hline Total & 48 & 100 \\
\hline
\end{tabular}

It is a known fact that consulting physicians do not respond in the time that is anticipated by the body of law. Some of the consultants even give this service via the phone or by other methods with- out seeing the patient $(8,9)$. When it is taken into consideration that the consulting physician is just as responsible as the emergency service physician in terms of vocational and administrative perspectives, it is an obligation for him/her to accept the consultation invitation. Leaving the consultation invitation unanswered is a crime and legally evaluated as "neglect of duty" (20). According to our study, "delay by the consulting physician" is placed fourth and "Consulting physician does not examine the patient, only gives information via the phone" is placed in the sixth place in the list of basic problems of emergency physicians.

With respect to conducting consultation responses in a shorter time period, Şahin et al. stated that forming paging systems for consulting physicians will contribute to the process (11).

In a study conducted by Şahin et al. (11), which included emergency physicians who request consultation, it was revealed that the major problems are not making a proper physical examination before the consultation invitation, not having consultation papers, not having enough information on the consultation request forms, and request for unnecessary consultations. In other studies conducted on this subject, it was observed that an invitation of a consulting physician without the correct indication is the most serious criticism $(8,9)$. The results of our study corresponded to these studies and showed that a physician who requests for consultation did not examine the patient thoroughly, the patient file did not contain adequate information, and unnecessary consultation was requested.

When we look at the solution recommendations that are revealed by the survey toward all of these problems, it says that unnecessary extra consultations, consulting physician's manner and behavior, adoption of patient, and communication problems must be solved. A similar result is revealed by Şahin et al. (11), which shows that these problems are general.

\section{Conclusion}

As a result, it is evident that in the solutions of problems encountered during the $\mathrm{CP}$, both ES and consulting physicians are responsible. In this respect, emergency service physicians must properly examine patients before requesting consultation and avoid unnecessary consultation invitations, whereas consulting physicians must not try to require diagnostic procedures to be completed in an ES and should not try to make the patients who would normally need hospitalization be treated in an ES. This will be the appropriate approach to solve the problems. In addition, having a more respectful behavior towards emergency physicians by the consulting physician is another thing that will result in the desired conditions.

Ethics Committee Approval: Our study is not required that the Ethics Committee Approval for a survey.

Informed Consent: Our study is no need for patient Informed Consent is a survey.

Peer-review: Externally peer-reviewed.

Conflict of Interest: No conflict of interest was declared by the authors.

Financial Disclosure: The authors declared that this study has received no financial support. 


\section{References}

1. Dölek M, Turaba F, Akbinar C, Sezgin B, Aksu H, Solak I. The satisfaction levels of patients staying in emergency department of Ege University Medical Faculty Hospital. Tr J Emerg Med 2005; 5: 122-7.

2. Available from: http://www.kalite.saglik.gov.tr/content/images/system/haberler_yeni/2011/01_Nisan_2011/deg.kitabi.pdf (Erişim tarihi 03.08.2013).

3. Türkan $\mathrm{H}$, Şener $\mathrm{S}$, Tuğcu H. Improper consultation process in emergency departments and its medico-legal aspects. Tr J Emerg Med 2005; 5: 13841.

4. Bulut $\mathrm{H}$. The effects of informing patients and their relatives on satisfaction at emergency units. Ulus Travma Acil Cerrahi Derg 2006; 12: 288-98.

5. Kavlu I, Pınar R. Effect of job satisfaction and burnout on quality life in nurses who work in emergency services. Türkiye Klinikleri J Med Sci 2009; 29: 1543-55.

6. Thomas DC. The contex as a moral rule inmedical ethics. J Bioeth 1984; 5 : 63-79. [CrossRef]

7. Smith DH. Ethics in the doctor- patient relationship. Crit Care Clin 1996; 12: 179-97. [CrossRef]

8. Holiman CJ. The art of dealing with consultants. J Emerg Med 1993; 11: 633-40. [CrossRef]

9. Genç M, Eğri M, Pehlivan E, Kırımlıoğlu V, Yılmaz S. A study on waiting times of the patients applying an emergency department. Turgut Özal Tip Merkezi Dergisi 1999; 6: 337-9.

10. Serinken M, Tomruk Ö, Erdur B, Sosyal S, Çımrın AH. Job stressors of emergency physicians. Eurasian J Emerg Med 2003; 1: 48-51.
11. Şahin H, Yürekli BS, Karaca B, Akçiçek F. The (Re) arrangement of hospital consultation services: a needs assesment study: scientific letter. Türkiye Klinikleri J Med Sci 2009; 29: 724-32.

12. Al B, Yıldırım C, Togun I, Zengin S, Bozkurt S, Köse A, Sohbet R. Factors that affect patient satisfaction in emergency department. Eurasian $J$ Emerg Med 2009; 8: 39-44.

13. Yiğit Ö, Oktay C, Bacakoğlu G. Analysis of the patient satisfaction forms about Emergency Department services at Akdeniz Univesity Hospital. Turk J Emerg Med 2010; 10: 181-6.

14. Barber Perez P, Gonzalez Lopez-Valcarcel B. Stimulation of a hospital emergency department and its potential use in management. Gac Sanit 1994; 8: 239-47.

15. Türk Tabipler Birliği hekimlik meslek etiği kuralları, Madde 19.(Yayın Tarihi : 01.02.1999).

16. Yancı H, Boz B, Demirkıran Ö, Kılıççıoğlu B, Yağmur F. Medical personal subjected to the violance in emergency department-enquiry study. $\operatorname{Tr} J$ Emerg Med 2003; 3: 16-20.

17. Sucu G, Cebeci F, Karazeybek E. Violence by patient and relatives against emergency service personnel. Tr J Emerg Med 2007; 7: 156-62.

18. La Coursiere DY, Nager CW. A comparison o two models of gynecology service consultation to the emergency departmen in an academic medical center. Am J Obstet Gynecol 2003; 188: 1166-8. [CrossRef]

19. Vissers MC, Hasman A, vd Linden CJ. Consultation behaviour of residents supported with a protocol processing system (protoVIEW) at the emergency ward. Int J Biomed Comput 1995; 38: 181-7. [CrossRef]

20. Hancı IH. Hekimin Yasal Sorumlulukları (Tıbbi Hukuk), Egem Tıbbi Yayıncilık, İzmir, 1995: 75-112. 